doi: $10.2306 /$ scienceasia1513-1874.2013.39.105

\title{
Ecological importance and biological resource conservation of Boraphet marsh, Thailand
}

\author{
Ratcha Chaichana $^{\mathrm{a}, \mathrm{b}, *}$, Sansanee Choowaew ${ }^{\mathrm{c}}$ \\ a Department of Environmental Technology and Management, Faculty of Environment, Kasetsart University, \\ Thailand \\ b Centre for Advanced Studies in Tropical Natural Resources, NRU-KU, Kasetsart University, Thailand \\ c Faculty of Environment and Resource Studies, Mahidol University, Thailand
}

*Corresponding author, e-mail: fscircc@ku.ac.th

Received 9 Dec 2012

Accepted 20 Feb 2013

\begin{abstract}
Boraphet marsh, the biggest shallow lake of Thailand, provides an important protein source and income for people in the upper north central region and provides a significant habitat for aquatic flora and fauna. The lake is divided into two zones including the strictly non-fishing and fishing zones with the main purposes of conserving rich biological resources. Here we investigated differences of water quality as well as aquatic resources between the strictly non-fishing and fishing zones. The results revealed that quality of water between the two zones was not significantly different with the exception of ammonium nitrogen and soluble reactive phosphorus that were higher in the strictly non-fishing zone. This could be the result of development projects (guest houses and restaurants) in the strictly non-fishing zone. Most species of biological resources was comparable between the two zones. However, species of macrophyte appeared to be higher in the fishing zone. Also, fish species and productivity in the strictly non-fishing zone were significantly higher than in the fishing zone and this might be the result of over-exploitation or perhaps together with the use of illegal and destructive fishing gears. In conclusion, the conservation zone implemented since 1947 has been successful as indicated by higher fish production than in the fishing zone. However, enhancing aquatic resource production in the fishing zone and promoting wise use of natural resources are still needed for future sustainable conservation of Boraphet marsh.
\end{abstract}

KEYWORDS: fish, shallow lake, water quality

\section{INTRODUCTION}

Boraphet marsh is the largest semi-natural shallow lake in Thailand, which was created in 1927 by the construction of a weir at the outlet of the lake to increase an open water area and a fish habitat ${ }^{1}$. Boraphet marsh has high socio economic values, especially tourism, fisheries, and aquaculture. It is one of the main sources of protein from high fishery production for local people in upper north of central region of Thailand. It is reported that around 300000 people live around the lake ${ }^{2}$ and make use of natural freshwater resources such as fish and water lilies. Boraphet marsh also serves as a source of water supply for domestic consumption, irrigation and agriculture as well as flood control. Ecologically Boraphet marsh also plays a very crucial role as a habitat of nearly 200 species of aquatic flora and fauna ${ }^{3}$.

In 1947, Ministry of Agriculture divided the lake into two zones including the strictly non-fishing zone and the fishing zone with allowance of specific and non destructive fishing gears. This was intended to preserve fish diversity and to increase fishery production in the lake. However, Boraphet marsh is now threatened by several factors. It is reported that soil erosion and the dissolution of water soluble salts from Nan River that supplies water to the lake may introduce lower water quality ${ }^{2}$. Expansion of agriculture, especially rice cultivation, may also affect nutrient addition from fertilizers as well as the availability of water in Boraphet marsh mostly during the dry season $^{1}$. Shortage of water not only impacts functions of the lake ecosystem ${ }^{4,5}$ but can also lead to conflict among farmers and other users. Over exploitation of natural resources, especially fish, is another serious issue at Boraphet marsh. There is still illegal fishing in a strictly non fishing zone together with uses of prohibited fishing gears such as electro-fishing and anaesthetic chemical substances in a fishing area. Illegal fishing may lead to destruction of the whole fish production of Boraphet marsh. Most importantly climate change may have direct effects on Boraphet marsh including changing hydrology, magnitude and seasonality of runoff regimes that alter nutrient load- 
ing and water quantity, warmer temperatures that alter availability of fish habitat, and changing water quality such as decreasing dissolved oxygen that alter fish community composition and dynamics ${ }^{6}$.

Boraphet marsh is susceptible to pressures such as changes in water quality and over exploitation of natural resources that may have led to reduction of biodiversity and deterioration of water quality and thus decreasing ecological and sociological importance. The main objective in this study was to investigate the current of water quality and biological resources of Boraphet marsh. We also compared limnological characteristics including physical, chemical, and biological components between strictly non fishing and fishing zones. The outcome of this study will be beneficial to the future management of the lake that may have suffered from natural and anthropogenic impacts. If managed properly, a healthy lake can promote a greater ecological value and can support a greater variety of aquatic plants and animals as well as human well being.

\section{MATERIALS AND METHODS}

Located in upper north of central part of Thailand, Boraphet marsh has an area of $148 \mathrm{~km}^{2}$ and has a mean depth average of $1.2 \mathrm{~m}$. Geographical location of the lake is between latitude $15^{\circ} 40^{\prime} \mathrm{N}$ (UTM Zone 47, $1732407 \mathrm{~m} \mathrm{~N})$ and $15^{\circ} 45^{\prime} \mathrm{N}(1741767 \mathrm{~m} \mathrm{~N})$ and longitude $100^{\circ} 10^{\prime} \mathrm{E}(625350 \mathrm{~m} \mathrm{E})$ and $100^{\circ} 23^{\prime} \mathrm{E}$ $(648260 \mathrm{~m} \mathrm{E})^{1}$ of Nakhon Sawan Province (Fig. 1). The lake as mentioned earlier is divided in two areas; a strictly non fishing zone that has an area of approx. 38800 rai and a fishing zone covering a larger area of some 93800 rai (6.25 rai is equal to $1 \mathrm{ha}$ ).

We established eight sampling stations (four stations in the strictly non fishing zone and the four stations in the fishing zone) throughout the lake (Fig. 2). Water and biological samples were both taken in open water and littoral areas of the two zones of the lake. Water and biological samples were collected seasonally three times in May (dry season), August (rainy season), and December (cold season) of 2011. Measurements of temperature $\left({ }^{\circ} \mathrm{C}\right)$, total dissolved solid, $\mathrm{pH}$, conductivity $(\mu \mathrm{S} / \mathrm{cm})$ and dissolved oxygen values using a multi meter were recorded in situ. Transparency was also investigated using a black and white Secchi disc. Three litres of water were taken from each sampling station at the depth of $1 \mathrm{~m}$ below water surface and then kept in plastic bottles at $4{ }^{\circ} \mathrm{C}$ for further chemical analysis in the laboratory. Chemical parameters included soluble reactive phosphorus (SRP, $\mu \mathrm{g} / \mathrm{l})$, nitrate nitrogen $\left(\mathrm{NO}_{3}^{-}-\mathrm{N}, \mathrm{mg} / \mathrm{l}\right)$, ammonium nitrogen $\left(\mathrm{NH}_{4}^{+}-\mathrm{N}, \mu \mathrm{g} / \mathrm{l}\right)$, total nitrogen

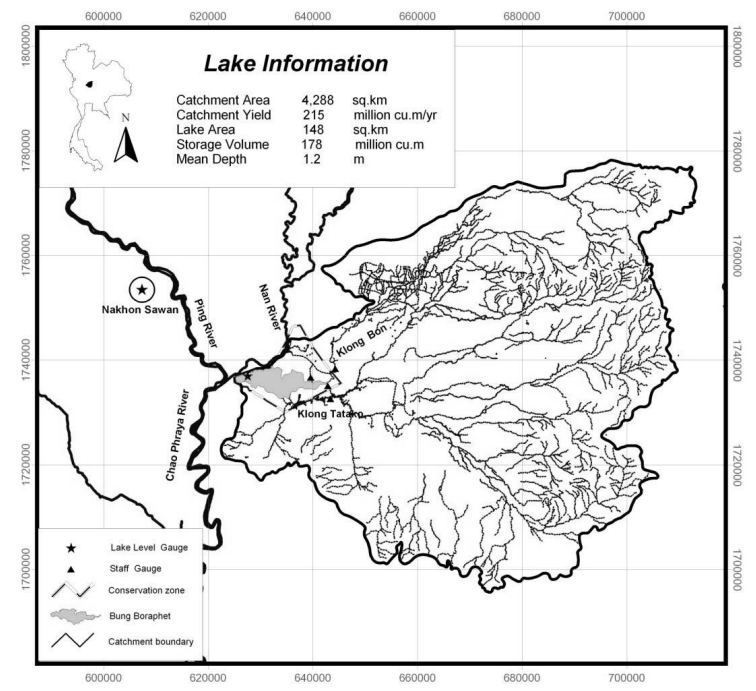

Fig. 1 Map of Boraphet marsh and the whole catchment area (source: Sriwongsitanon et $\mathrm{al}^{1}$ ).

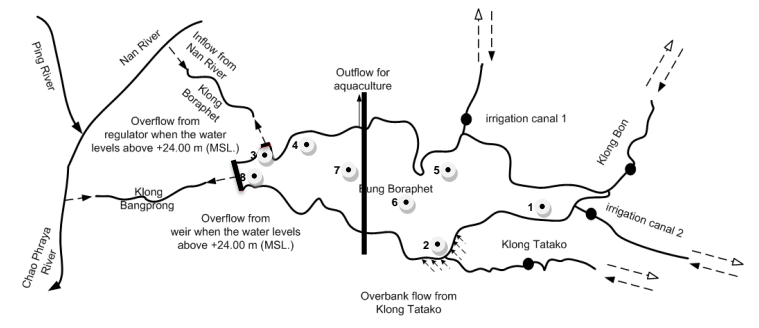

Fig. 2 Strictly non fishing and fishing zones and 8 sampling stations (1-8) in Boraphet marsh (Map modified ${ }^{1}$ ).

(TN, mg/l) and total phosphorus (TP, $\mu \mathrm{g} / \mathrm{l})$ based on standard methods for the examination of water and waste water ${ }^{7}$. Concentrations of chlorophyll a were also investigated by filtering of $150 \mathrm{ml}$ of water samples through Whatman glass microfibre filters (GF/C, $47 \mathrm{~mm}$ ) and then used a standard acetone extraction $\operatorname{method}^{7}$.

Phytoplankton and zooplankton samples were collected by passing 51 of water from each sampling station through plankton nets with a mesh size of 20 and $63 \mu \mathrm{m}$, respectively. Subsequently plankton samples were preserved in $70 \%$ ethanol in plastic bottles. Both phytoplankton and zooplankton were identified up to species level and counted in a subsample using an inverted microscope.

Sedimentary invertebrates were sampled using an Ekman grab $(15 \mathrm{~cm} \times 15 \mathrm{~cm} \times 20 \mathrm{~cm})$. Samples were transferred to wide-mouthed plastic bottles and preserved with $70 \%$ ethanol. All samples were sieved through a 335- $\mu \mathrm{m}$ mesh sieve and then were sorted 
from spreads on a white tray. All benthic macroinvertebrate taxa were identified to Genus level.

Invertebrates associated with the plants were also studied using a $250 \mu \mathrm{m}$ mesh net swept for $1 \mathrm{~min}$ through the plant bed. Animals were transferred to wide-mouthed plastic bottles and preserved with 70\% ethanol and then samples were sorted, identified to up to Genus level and counted.

Surveys of macrophytes were carried out by using a $1 \mathrm{~m} \times 1 \mathrm{~m}$ quadrat placed three times in each sampling station. Plants present in a quadrat were identified to species level.

Fishes were also sampled in littoral zone with a large beach seine net $(2.5 \mathrm{~m} \times 15 \mathrm{~m}, 1-\mathrm{mm}$ mesh size) pulled by men, one or more on either end of the net. The netted fish were hauled to the canal bank where the fish specimens were identified to species level and then counted, measured for total length (TL, $\mathrm{cm}$ ), weighed (g), and photographed. Pelagic fishes were captured by gill nets at three different mesh sizes $(1.5,5$, and $12 \mathrm{~cm})$ for small, young and adult fishes. Gill nets were left overnight in the lake and the following day all nets were retrieved. Fish samples were identified to species level, counted, measured for total length (TL, cm), weighed (g), and photographed.

We used SPSS 14.0 for Windows for statistical analyses. Student $t$-test was applied to determine differences of water and biological parameters between the strictly non fishing and fishing zones (sample sizes $=12$ for each zone). Values present throughout are given as means \pm standard deviation and numbers of samples measured.

\section{RESULTS}

The volume and quality of Boraphet marsh changed seasonally and spatially. Especially in late 2011 during the rainy and cold seasons there was severe flooding in Boraphet marsh and across northern and central regions of Thailand due to the strong effect of La Niña phenomenon. Generally water quality of Boraphet marsh was in good condition such as dissolved oxygen $(7 \pm 13 \mathrm{mg} / \mathrm{l})$ and $\mathrm{pH}(7.8 \pm 0.5)$ (Table 1) and met water quality standards of inland waters ${ }^{8}$. Average depth of Boraphet marsh measured from eight stations was $1.8 \pm 1.0 \mathrm{~m}$ and the maximum water depth was at $4.4 \mathrm{~m}$. Nutrient concentrations of Boraphet marsh in general were rather low (mean total nitrogen $(0.2 \pm 0.5 \mathrm{mg} / \mathrm{l})$ and mean total phosphorus $(10.0 \pm 0.7 \mu \mathrm{g} / \mathrm{l})$ and can be classified as a mesotrophic lake. TN:TP ratio also suggested that the lake was phosphorus limited with TN:TP ratio by mass higher than 10. Chlorophyll concentrations were also low $(2.2 \pm 2.6 \mu \mathrm{g} / \mathrm{l})$ as in an oligotrophic lake with
Table 1 Comparison of mean water quality measured between the strictly non fishing and fishing zones of Boraphet marsh in 2011.

\begin{tabular}{lcc}
\hline Parameters & $\begin{array}{c}\text { Fishing } \\
\text { zone }\end{array}$ & $\begin{array}{c}\text { Strictly non } \\
\text { fishing zone }\end{array}$ \\
\hline Temperature $\left({ }^{\circ} \mathrm{C}\right)$ & $31 \pm 5^{\mathrm{a}}$ & $30 \pm 3^{\mathrm{a}}$ \\
$\mathrm{pH}$ & $7.6 \pm 0.5^{\mathrm{a}}$ & $7.9 \pm 0.3^{\mathrm{b}}$ \\
Conductivity $(\mu \mathrm{S} / \mathrm{cm})$ & $600 \pm 1200^{\mathrm{a}}$ & $240 \pm 40^{\mathrm{a}}$ \\
Total dissolved solid $(\mathrm{g} / \mathrm{l})$ & $1.3 \pm 1.5^{\mathrm{a}}$ & $0.14 \pm 0.04^{\mathrm{b}}$ \\
Transparency $(\mathrm{m})$ & $0.7 \pm 0.2^{\mathrm{a}}$ & $0.6 \pm 0.3^{\mathrm{a}}$ \\
Dissolved oxygen $(\mathrm{mg} / \mathrm{l})$ & $6.2 \pm 2.7^{\mathrm{a}}$ & $6.6 \pm 1.9^{\mathrm{a}}$ \\
Ammonium $(\mu \mathrm{g} / \mathrm{l})$ & $1 \pm 4^{\mathrm{a}}$ & $6 \pm 9^{\mathrm{b}}$ \\
Nitrate $(\mathrm{mg} / \mathrm{l})$ & $0.23 \pm 0.06^{\mathrm{a}}$ & $0.22 \pm 0.06^{\mathrm{a}}$ \\
Total nitrogen $(\mathrm{mg} / \mathrm{l})$ & $1.8 \pm 0.7^{\mathrm{a}}$ & $1.8 \pm 0.8^{\mathrm{a}}$ \\
Soluble reactive & $0.7 \pm 0.7^{\mathrm{a}}$ & $1.2 \pm 0.7^{\mathrm{b}}$ \\
phosphorus $(\mu \mathrm{g} / \mathrm{l})$ & & \\
Total phosphorus $(\mathrm{mg} / \mathrm{l})$ & $0.02 \pm 0.03^{\mathrm{a}}$ & $0.03 \pm 0.02^{\mathrm{a}}$ \\
Chlorophyll a $(\mu \mathrm{g} / \mathrm{l})$ & $1.8 \pm 2.4^{\mathrm{a}}$ & $2.5 \pm 2.8^{\mathrm{a}}$ \\
\hline
\end{tabular}

Values are given as means \pm standard deviation, $n=12$. Mean values followed by different letters are significantly different $(p<0.05)$.

concentration lower than $3 \mu \mathrm{g} / \mathrm{l}$.

We compared water quality between the strictly non fishing and fishing zones and it was found that most measures of water quality measured were not significantly different. However, soluble reactive phosphorus and ammonium were significantly higher in the strictly non fishing zone than in the fishing zone. It was also revealed that total dissolved solid and $\mathrm{pH}$ values were significantly different between the strictly non fishing and fishing zones.

The results of biological sampling revealed that there were 93 species of phytoplankton in Boraphet marsh and Microcystis aeruginosa (Kutzing) and Aulacoseira granulata (Ehrenberg Simonsen) were the most abundant species. A total 43 species of zooplankton was recorded. Rotifer were the dominant group and Tintinnopsis lohmani (Gaw \& Kung) and Keratella tropica (Apstein) were dominant. Densities of phytoplankton and zooplankton are shown in Table 2. There were 53 genera of benthic macro invertebrates and major genera present included Nais and Chironomus. In terms of invertebrates associated with plants, we found 47 genera. Freshwater shrimp, Caridina sp., was the most abundant genus as well as Pomacea and aquatic insects namely Ilyocoris sp. and Baetis. There are 77 species of fish. Main littoral fish included Trichopsis pumila (Arnold), Trichopsis vittatus (Cuvier), Pristolepis fasciatus (Bleeker) and major pelagic fish were Parachela siamensis (Gunther), Parambasis siamensis (Fowler) and Corica soborna 
Table 2 Comparison of species and abundance of biological resources between the strictly non fishing and fishing zones.

\begin{tabular}{|c|c|c|c|c|}
\hline \multirow[t]{2}{*}{ Biological resources } & \multicolumn{2}{|c|}{ Species (actual number) } & \multicolumn{2}{|c|}{ Density } \\
\hline & $\begin{array}{l}\text { Fishing } \\
\text { zone }\end{array}$ & $\begin{array}{l}\text { Strictly non } \\
\text { fishing zone }\end{array}$ & $\begin{array}{l}\text { Fishing } \\
\text { zone }\end{array}$ & $\begin{array}{l}\text { Strictly non } \\
\text { fishing zone }\end{array}$ \\
\hline Phytoplankton & 80 & 60 & $11000 \pm 14000 \mathrm{cell} / 1^{\mathrm{a}}$ & $20000 \pm 50000{\text { cell/ } / 1^{\mathrm{b}}}$ \\
\hline Zooplankton & 35 & 28 & $700 \pm 700$ animals $/ 1^{a}$ & $1300 \pm 1300$ animals $/ 1^{a}$ \\
\hline $\begin{array}{l}\text { Benthic macro } \\
\text { invertebrates }\end{array}$ & 20 & 18 & $135 \pm 5$ animals $/ \mathrm{m}^{2}$ a & $189 \pm 9$ animals $/ \mathrm{m}^{2} \mathrm{a}$ \\
\hline $\begin{array}{l}\text { Invertebrates associated } \\
\text { with plants }\end{array}$ & 35 & 43 & $\begin{array}{c}70 \pm 4 \text { animals } / 1 \text { min } \\
\text { of collection }^{\text {a }}\end{array}$ & $\begin{array}{c}86 \pm 4 \text { animals } / 1 \text { min } \\
\text { of collection }^{\text {a }}\end{array}$ \\
\hline Aquatic macrophytes & 15 & 23 & $36 \%$ cover $/ \mathrm{m}^{2}$ a & $34 \%$ cover $/ \mathrm{m}^{2 \mathrm{~b}}$ \\
\hline Littoral fish & 34 & 37 & $300 \pm 900 \mathrm{~kg} / 100 \mathrm{~m}^{2} \mathrm{a}$ & $1300 \pm 3200 \mathrm{~kg} / 100 \mathrm{~m}^{2} \mathrm{~b}$ \\
\hline $\begin{array}{l}\text { Pelagic fish captured } \\
\text { by different mesh sizes; }\end{array}$ & & & & \\
\hline $1.5 \mathrm{~cm}$ & 20 & 35 & $600 \pm 1300 \mathrm{~kg} / 100 \mathrm{~m}^{2} \mathrm{a}$ & $300 \pm 600 \mathrm{~kg} / 100 \mathrm{~m}^{2} \mathrm{a}$ \\
\hline $5 \mathrm{~cm}$ & 36 & 31 & $500 \pm 700 \mathrm{~kg} / 100 \mathrm{~m}^{2} \mathrm{a}$ & $1100 \pm 1900 \mathrm{~kg} / 100 \mathrm{~m}^{2} \mathrm{~b}$ \\
\hline $12 \mathrm{~cm}$ & 27 & 50 & $1100 \pm 1200 \mathrm{~kg} / 100 \mathrm{~m}^{2} \mathrm{a}$ & $1700 \pm 3400 \mathrm{~kg} / 100 \mathrm{~m}^{2} \mathrm{~b}$ \\
\hline
\end{tabular}

Values are given as means \pm standard deviation, $n=12$.

Mean values followed by different letters are significantly different $(p<0.05)$.

(Hamilton). A total of 23 species of macrophytes were recorded in Boraphet marsh. Eichhornia crassipes (Hart. Solms) and Salvinia cucullata (Roxb) were the most common macrophytes in the lake.

Comparative analysis of phytoplankton populations between the strictly non fishing and fishing zones revealed that phytoplankton populations in strictly non fishing zone were significantly higher than in the fishing zone (Table 2). In contrast, densities of zooplankton communities, benthic macro invertebrates and invertebrates associated with plants were not significantly different between the two zones. Percent cover of aquatic macrophytes was significantly higher in the fishing zone than in the strictly non fishing zone.

Littoral fish production between the strictly non fishing and fishing zones was significantly different. We also compared pelagic fish production (weight measured) by mean of three different mesh sizes (1.5, 5 , and $12 \mathrm{~cm}$.) of gill nets. It was found that fish production caught by gill net of $1.5 \mathrm{~cm}$ mesh size in the fishing zone was not significantly different from the strictly non fishing zone. In contrast, production of fish captured by gill nets of 5 and $12 \mathrm{~cm}$. mesh size in the strictly non fishing zone was significantly higher than in the fishing zone.

In terms of species diversity between the two zones, it was revealed phytoplankton, zooplankton, benthic macroinvertebrates and invertebrates associated with plants were comparable. However, aquatic macrophyte species were greater in the fishing zone than in the strictly non fishing zone. Results of fish diversity also revealed that in the strictly non fishing zone there were more species than in the fishing zone.

\section{DISCUSSION}

Overall water quality of Boraphet marsh was in good conditions and was comparable with previous studies. For instance, dissolved oxygen $(7 \pm 13 \mathrm{mg} / \mathrm{l})$ measured in $2009^{2}$ was relatively similar with that investigated in this study $(6.4 \pm 2.3 \mathrm{mg} / \mathrm{l})$. This indicates that dissolved oxygen has not changed greatly in the past few years. This may be explained by the fact that Boraphet marsh is connected to the Nan River and during the annual raining season enormous amounts of water from the Nan flushes out contaminants from the lake and thus maintaining its high water quality. This process may be similar to that in an Amazon flood plain lake, where river water invades the lake at the starting of rising water and then lake water steadily flowed out from the lake and into the river, while river levels continued to rise ${ }^{9}$. High flushing rate of a lake usually results in a low concentration of nutrients in the lake water ${ }^{10}$.

Nutrient concentrations were significantly different between the strictly non fishing and fishing zones and this could be the result of some development projects of local government. The local government has continuously tried to promote tourism in this area by providing all facilities such as guest houses, restaurants and artificial sandy beach for tourists. Also, there is a fishery research station nearby together with a floating raft provided for tourists to artificially feed fish in the lake. Waste water containing high organic and inorganic substances from development projects 
could contaminate the lake as well as left over fish food from feeding fish that may have caused higher concentrations of ammonium and SRP in the strictly non fishing zone. The result of fish culture in the lake in China ${ }^{11}$, similar to this case, showed that mass-input of exogenous nutrients may cause negative effects on water quality as seen in Boraphet marsh.

Higher phytoplankton population corresponded well with higher concentrations of plant nutrients in the strictly non fishing zone. In contrast, lower populations of phytoplankton in the fishing zone could be the result of luxury uptake of nutrients by aquatic submerged vegetations that are mainly dominated in such area and thus limiting growth of phytoplank$\operatorname{ton}^{12,13}$. Zooplankton was abundant in the strictly non fishing zone but did not influence phytoplankton populations. This could be explained by low grazing effects of small zooplanktons mainly rotifers that was dominant in the strictly non fishing zone ${ }^{12,14}$. It was also found that abundance of vegetation in this study is related to the area of the study site (the fishing zone) since species richness of macrophytes increased markedly with lake size ${ }^{15}$.

The creation of freshwater protected areas is addressed in several studies since freshwater species and habitats are among the most threatened in the world ${ }^{13,16,17}$. Strictly non fishing or fish conservation zone in Boraphet marsh, for example, has also proven to be effective and successful. According to the results, overall fish diversity and production was significantly higher in the strictly non fishing zone than in the fishing zone. In particular, we found that in the strictly non fishing zone production of littoral fish as well as large or adult fishes (capture by gill nets of 5 and $12 \mathrm{~cm}$ mesh sizes) were higher than in the fishing zone. In addition, in the fishing zone, production of small fish with lower economic values such as Parachela siamensis and Parambasis siamensis was relatively high. The comparison between fished and reserve areas in Lake Kariba also showed similar result that there was a significant reduction in mean length of commercially fished species in the fished areas as well as a higher abundance of noncommercial species ${ }^{16}$.

Reduction of fish production in Boraphet marsh reflects the fact that there is over exploitation of fish resources in the fishing zone or perhaps by the use of illegal and prohibited fishing gears and methods ${ }^{18}$. It is reported that there are approximately 5100 fishermen in Boraphet marsh and each day around 76 fishermen capture in average $24.75 \mathrm{~kg}$ of fish per person and fishing usually takes place 25 days per month ${ }^{19}$. Intensive fishing activities undoubtedly can cause reduction of fish production. Although fish production in the fishing zone was relatively low, high fish biodiversity and production in the strictly non fishing zone may help maintain fish population in the whole Boraphet marsh.

The introduction of invasive exotic species is globally recognized as one of the most serious threats to native biodiversity ${ }^{17,20-22}$. In Boraphet marsh as in many other lakes, the presence of aquatic invasive species is of concern too. We found non-indigenous invasive species of plants and animals including water hyacinth (Eichhornia crassipes (Mart)), giant sensitive tree (Mimosa pigra (Linnaeus)) and armoured sucker mouth catfish (Pterygoplichthys pardalis (Castelnau)) in the lake. In particular armoured sucker mouth catfish, can destroy eggs and first feeding fry of other fish ${ }^{23,24}$. Therefore it has potential to reduce fish biodiversity of Boraphet marsh in the future if the population of such species increases. Freshwater protected areas should contain no non-native species ideally ${ }^{17}$.

In conclusion overall Boraphet marsh had a high water quality and can support aquatic flora and fauna. However, any further development around the lake should be taken into account carefully especially anthropogenic environmental impact that may deteriorate quality of the lake. Implementation of the strictly non fishing zone shows high satisfaction that has helped conserve biodiversity as well as biological productions. Further resource enhancement, regulations and conservation practices such as closed fishing season and fish stocking should be implemented in the fishing zone to enhance fishery resources as well as a greater variety of fish. Threats to Boraphet marsh particularly invasive non indigenous species are of concern and should be monitored every year. Successful management will be beneficial to not only the people relying on natural resources of Boraphet marsh but also to sustainable aquatic resource conservation.

Acknowledgements: We were grateful to Mahidol University for financial support in the research project of "Participatory Research for Conservation and Sustainable Wise Use of Bung Boraphet Wetlands". We were also thankful to staff of Mahidol University, Nakhonsawan campus for their assistance and accommodation during field work in Boraphet marsh. Lastly, we thanked Centre for Advanced Studies in Tropical Natural Resources, NRU-KU, Thailand for the work at Kasetsart University.

\section{REFERENCES}

1. Sriwongsitanon N, Surakit K, Hawkins PR, Chandrasena N (2007) Decision support tools for water 
resource management: a case study of Bung Boraphet wetland, Thailand. J Dev Sustain Agr 2, 17-26.

2. Netpae T, Phalaraksh C (2009) Bioaccumulation of copper and lead in Asian clam tissues from Bung Boraphet reservoir, Thailand. Int J Agr Biol 11, 783-6.

3. Office of Natural Resources Environmental Policy Planning (2003) Biodiversity in Bung Boraphet Wetland. Ministry of Natural Resources and Environment, Bangkok, p 146.

4. Linda D, Mortsch LD, Quinn FH (1996) Climate change scenarios for great lakes basin ecosystem studies. Limnol Oceanogr 41, 903-11.

5. Meyer JL, Sale MJ, Mulholland PJ, Poff NL (1999) Impacts of climate change on aquatic ecosystem functioning and health. J Am Water Resour Assoc 35, 1373-86.

6. Winder M, Schindler DE (2004) Climate changes uncouples trophic interactions in an aquatic ecosystem. Ecology 85, 2100-6.

7. APHA, AWWA, WEF (2005) Standard Methods for the Examination of Water and Wastewater, 21 edn, American Public Health Association. Washington, D.C.

8. Department of Pollution Control (2000) Water Quality Standards and Criteria in Thailand, 4 edn, Ministry of Science, Technology and Environment, Bangkok.

9. Lesack LFW, Melack JM (1995) Flooding hydrology and mixture dynamics of lake water derived from multiple sources in an Amazon floodplain lake. Water Resour Res 31, 329-45.

10. Efford IE (1967) Temporal and spatial differences in phytoplankton productivity in Marion lake, British Columbia. J Fish Res Board Can 24, 2283-307.

11. Guo L, Li Z (2003) Effects of nitrogen and phosphorus from fish cage-culture on the communities of a shallow lake in middle Yangtze river basin of China. Aquaculture 226, 201-12.

12. Moss B, Madgwick J, Phillips G (1997) A Guide to the Restoration of Nutrient-Enriched Shallow Lakes, W. W. Hawes, London.

13. van Donk E, van de Bun WJ (2002) Impact of submerged macrophytes Including charophytes on phytoand zooplankton communities: allelopathy versus other mechanisms. Aquat Bot 72, 261-74.

14. Chaichana R, Leah R, Moss B (2011) Conservation of pond systems: a case study of intractability, Brown Moss, UK. Hydrobiologia 664, 17-33.

15. Sondergaard M, Jeppesen E, Jensen JP (2005) Pond or lake: does it make any difference? Arch Hydrobiol 162, 143-65.

16. Sanyanga RA, Machena C, Kautsky N (1995) Abundance and distribution of inshore fish in fished and protected areas in Lake Kariba, Zimbabwe. Hydrobiologia 306, 67-78.

17. Saunders DL, Meeuwig JJ, Vincent ACJ (2002) Freshwater protected areas: strategies for conservation. Conservat Biol 16, 30-41.

18. Miao W, Silva SD, Davy B (2010) Inland Fisheries
Enhancement and Conservation in Asia. FAO Regional Office for Asia and the Pacific RAP Publication 2010/22, Bangkok, p 189.

19. Bung Boraphet Tourist Center (2012) Fishing in Bung Boraphet. http://www.buengboraphet.com/History6. html.

20. Lodge DM, Stein RA, Brown KM, Covich AP, Brönmark C, Garvey JE, Klosiewski SP (1998) Predicting impact of freshwater exotic species on native biodiversity: challenges in spatial scaling. Aust J Ecol 16, 53-67.

21. Schmitz DC, Schardt JD, Leslie AJ, Dray Jr, FA, Osborne JA, Nelson BV (1991) The ecological impact and management history of three invasive alien aquatic plant species in Florida. In: McKnight BN (ed) Biological Pollution: the Control and Impact of Invasive Exotic Species, Indiana Academy of Science, Indianapolis, pp 173-94.

22. Skelton PH (1990) The conservation and status of threatened fishes in southern Africa. J Fish Biol 16,(supplement A), 87-95.

23. Cook-Hildreth SL (2009) Exotic armored catfishes in Texas: reproductive biology, and effects of foraging on egg survival of native fishes (Etheostoma fonticola), endangered and (Dionda diabolic), threatened. MSc thesis, Univ of Texas.

24. Nico LG, Martin RT (2001) The south american armored catfish, Pterygoplichthys anisitsi (Pisces: Loricariidae), in Texas, with comments on foreign fish introductions in the American Southwest. SW Nat 46, 98-104. 